\title{
GIFTED EDUCATION IN VARIOUS COUNTRIES OF EUROPE
}

\author{
Eva Reid - Heiner Boettger
}

\section{DOI: 10.18355/PG.2015.4.2.158-171}

\begin{abstract}
Nowadays, gifted education varies considerably from country to country. On one hand, there are countries with elaborated special gifted programmes, and on the other hand there are countries, which are not even recognising terms such as giftedness and gifted children. Most countries provide support of the gifted children with the help of various organizations. Apart of the system of schooling of the gifted, also organizations supporting the gifted children are mapped. Very often there is a view, even among educationalists, that gifted education is elitist and that gifted children would do just fine without any intervention. These are myths which when believed can inhibit the opportunity to maximise the potential of gifted children. Gifted children require special attention, otherwise their talents can be lost without noticing. This article is a part of greater holistic research on gifted education and it particularly discusses different ways the gifted children are educated in several countries in Europe.
\end{abstract}

\section{Key words}

gifted education, gifted education in Europe, talented, gifted

\section{Introduction}

An overview of various school systems, definitions, supporting organizations of gifted education in ten European countries is described in this article. Information on gifted education in some countries is quite elaborate and supported with research findings. Specifically, gifted education in the United Kingdom, Austria, Germany, Switzerland, Spain, Denmark, Finland, Czech Republic, Hungary and Slovakia is mapped. Information on gifted education is not always accessible about all the analyzed countries, neither relevant research published in the English language.

\section{United Kingdom}

History of education of the gifted in the United Kingdom dates back to 1944, when a new School Act provided possibilities for talented children to study at newly created Grammar Schools. These were later viewed as elitist and local authorities were encouraged to close them down and replace them by Comprehensive schools, which were to provide equal opportunities for everybody. However, some Grammar Schools survived alongside a significant number of private fee paying schools (Casey, Koshy, 2012). UK's education system today aims to provide appropriate education to all the children, consequently the education of the gifted should be a part of a 
larger whole. The approach to gifted education in the whole of the UK is inclusive and holistic. There are differences within the UK though, for example, in England the terms "gifted" and "talented" are used and 5 to $10 \%$ of pupils in every school in England are considered to be gifted or talented. In Wales the terms "more able" and "talented" are used and up to $20 \%$ of pupils are considered to be more abled and talented. Scotland uses the term "able" and also covers the inclusive approach (Monks, Pfluger, 2005). The "English model" prefers the integrated approach to gifted education. Gifted children should spend most of their time with the regular school group (especially in the age 5-11) with a small amount of cross school and out of school opportunities.

Each school should recognize individual differences and should plan curriculum meeting the needs of individuals. This means that schools should plan to meet the needs of both, the gifted as well as the least able children. One of the ways is to divide a class to groups based on their abilities. With $14-19$ years old, there is the emphasis on personal routes to meet personal needs. School here is to provide optimum match between needs and opportunities. Every teacher in this integrated education must be also a teacher of the gifted and also, each teacher has the power to decide who is gifted (Eyre, 2009).

Knowing how difficult it is to recognize gifted children and how to nurture their needs, the teachers in England are given too much power and responsibility, which is usually provided by psychologist and teachers for children with special needs. Eyre (2004) believes that the educational process in England is not so much a question of intellect, but rather a question of affluence, with the most affluent receiving the best education. However, the Government's agenda was to increase gifted education in all schools and by 2007 all schools in England were supposed to have a school policy and a coordinator for the gifted pupils. It was believed that, where schools integrated programmes for the gifted as part of their overall plan, general educational standards would rise.

There were several organizations created to support the gifted in the UK. The National Association for Gifted Children was established in 1967 to support the social, emotional and learning needs of children with high learning potential of all ages and backgrounds (Potential Plus UK, 2014). National Association for Able Children in Education (NACE) was established in 1983 to support, guide and train teachers to attain the best from able learners in everyday classrooms. It also has a history of supporting schools overseas. In 2002 the National Academy for Gifted and Talented Youth (NAGTY) was established at the University of Warwick to help deliver the Government's programme for gifted and talented learners, in particular by developing, promoting and supporting educational opportunities for gifted and talented children up to the age of 19 (DE, 2009). In 2008 a government policy for supporting the gifted was issued under the National Programme for gifted and talented education (DCSF, 2008). It was to encourage schools in identifying gifted and talented learners focusing on 11-19 years old, who are gifted and talented relative to

Slavonic Pedagogical Studies Journal Vol. 4 Issue 2, September 2015 
their peers in their own group and school. Schools should focus on range of abilities, such as talents in the arts and sports, and ability rather than achievement, so the underachievers are amongst those identified. This programme is nowhere to be found any more and I could not find if it is still in operation. However, despite the positive evaluation of the NAGTY by the Department of Education (DE, 2009), more than 200,000 children receiving support, thousands of teachers being trained, the NAGTY was closed down in 2010 (Henry, 2010; Muray, 2010). According to Potential Plus UK (2014), the introduction of new teaching standards in 2012 expects schools to identify and support gifted children. It does not specify the needs of the gifted, but it focuses on progression for all pupils with the aim to meet the National Curriculum.

\section{Austria}

Gifted education in Austria dates back to 1962, when gifted education was explicitly mentioned in educational legislation. In 1970s an opportunity to skip classes for gifted children was allowed. Supporting children with special educational needs has a long tradition and in 1990s integrated education was a part of Austrian compulsory education. Gifted children, just like the slow learners, were recognized as learners with specific needs, interests, abilities and modes of thinking. In 1999 an Austrian Research and Support Center for the Gifted and Talented (ÖZBF) was established with the aim to provide support system for the gifted children, their parents and educators. In 2006 an early entry to compulsory schooling was allowed (Weilguny, Resch, Samhaber, Hartel, 2013).

With the General Decree on the Promotion of Giftedness and Talent issued by the Ministry for Education in 2009 (Weilguny, Resch, Samhaber, Hartel, 2013), all Austrian schools were to develop the potentials of the gifted and talented children. Basic principles for the promotion of giftedness and talent focus on strength and interests, accepting and supporting giftedness in an unbiased way, integrating giftedness and talent into the overall school culture. Schools should identify characteristics that are relevant to giftedness and talent, apply specific educational measure and provide feedback in a way that enhances motivation.

Austrian legislation emphasises a general idea of individualized education, acceleration and enrichment within regular schools as well as within specific schools. School legislation specifies that gifted children can skip classes, can be released from compulsory education, attend classes at universities and attend universities from the age of 15 . The more common education of the gifted pupils is within the regular classes, where they receive special attention through enrichment, workshops, individual mentors or various programmes regarding language, maths, science, music or sports. However, there are some schools which prefer segregated model of educating the gifted children. Regional, national and international "Olympiads" are frequently organized at all levels. Additionally, summer schools for gifted children are arranged. Identification of the gifted children is done by teachers and psychologists who use standardized tests (Oswald at al, 2005). School achievement is an indicator for high potential, 
which does not give many chances to the underachievers. However, the identification of underachievers is a topic of concern in Austria.

\section{Germany}

In Germany, the 16 federal states are responsible for their education system. The gifted education is mentioned in the legislation of some states, but all states promote flexible school system including early enrolment at primary schools and class skipping. Regular practices for gifted children are early enrolment at primary school, acceleration, grade skipping, taking classes with higher grades, cooperation with universities, extra-curricular syllabus, competitions and summer camps (Ziegler, Stoeger, Harder, Balestrini, 2013). Gifted children are identified by teachers, parents or even children themselves. Extraordinary school achievements are the precondition in the selection process. Some programmes use IQ tests for identification (Fisher et al, 2005). Ziegler, Stoeger,, Harder and Balestrini (2013) pointed out findings from the longitudinal research Malburg Giftedness Project from 2000 , which indicated that only $15 \%$ of high performers were gifted (above 125 IQ) and that in fact $15 \%$ of gifted students were underachievers. These findings question the belief that school performance goes hand in hand with intelligence. The issue of gifted underachievers in not found in the German education system. However the gifted education in Germany cannot be generalized, as the 16 federal states have variable systems, which should be inspected individually.

The system of college-preparatory secondary education for high achieving children Gymnasia dates back to the $18^{\text {th }}$ century. The tradition of Gymnasia exists to this day throughout Germany and it offers academic excellence. For instance, only 1\% of pupils completed Gymnasium in 1900, by 1930 the number has risen to $3 \%$ and the number of students that completed Gymnasium by 2010 reached 30\% (Ziegler, Stoeger, Harder, Balestrini, 2013).

Die Deutsche Gesellschaft für das hochbegabte Kind (DGhK, 2015) is a nation-wide non-profit organization which was established in 1978 and it provides help and special courses to gifted children, parents, whole families, educators and psychologists. The DGhK was established because of the experience that it cannot be taken for granted that gifted children are always high achievers. Gifted children can develop problems at school and in social interaction, if their intellectual needs are not recognized and developed. Today the DGhK has 15 regional organizations and more than 3,000 members. Hochbegabtenförderung e.V. is an organization, which was established in 1994 by parents of the gifted children. It operates in 25 towns all around Germany and it organizes weekend, afternoon, holiday courses for gifted children and counselling for parents and teachers (Persson, R.S, Joswig, H., Balogh, L, 2000). It has helped over 13 thousand children since 1994 (Bundesgeschäftsstelle Bochum, 2015).

\section{Switzerland}

Educational system in Switzerland is decentralized and it is organized autonomously by 26 cantons. The following information concerns the 
gifted education in the 19 German speaking cantons, which are integrated in a network for gifted education in Switzerland. Most of the school legislation of the Swiss cantons recognises gifted pupils, provides information about gifted education, or recognises gifted children as a part of a group of students with special needs. A common practice for the gifted is acceleration, early entrance, grade skipping and enrichment. The gifted are mainly organised within regular class differentiation, and in special cases can be released from compulsory education. Occasionally, education is carried out in specific segregated classes, but mostly for non-intellectual giftedness. Identification of the gifted is based on the teacher or self nomination. For skipping classes and sharing classes with higher grades, examination by a psychologist is necessary (Grossenbacher, 2005).

Meta analysis of gifted education in German speaking countries Germany, Austria and Switzerland - was carried out by Herman and Nevo in 2011. According to the authors, the notion of gifted education is relatively new in German speaking countries. A general dislike for anything connected with the advancement of elites is possibly connected to the history events during the Third Reich. There is also the assumption that gifted children would be sufficiently challenged in the regular education system. Herman and Nevo (ibid.) provided a detailed account of current gifted education in Germany, Austria and Switzerland. They reported that even though there are some differences between the three countries, the programmes offering education to the gifted children are very similar. All three countries include early enrolment at primary school, grade skipping, sharing classes with higher grades, early part time attendance of university, early exit from school to attend university, ability grouping, special schools for gifted children, school competitions and summer academies. Possible criteria for choosing gifted children to the special programmes are grades, school external achievement (competitions), performance tests (IQ), questionnaires (filled by the child, or the third party), parent checklist, nominations, as well as institutional criteria. Herman and Nevo (ibid.) also analysed the impact of various programmes on the gifted children. The outcomes from all types were very positive. However, all studies were carried out at the gymnasium level and they included only high achieving children, which does not always go hand in hand with ability. The top marks were always a condition for children to be accepted to the special programmes. These programmes would very unlikely suit the most vulnerable group of gifted children, who have asynchronous development and are often underachieving, or with social or behavioural problems.

\section{Spain}

Gifted education in Spain is explicitly mentioned in the Spanish legislation and gifted children are considered as students with special educational needs. Class sharing with higher grades, curricular adaptation and class skipping are possible, but rarely used in Spanish schools. There is a growing interest in provisions for gifted children, with curricular adaptations, or class skipping, but the specific school actions for the gifted 
are still rare. Schools regularly organise school competitions for the gifted children. Despite there is a legal obligation to identify the gifted children, there are no criteria for the gifted, nor the procedures or test instruments to identify the gifted. There is also very little attention paid to the teacher training of the gifted children. Even though the school legislation recognises gifted children, their education has been generally neglected (Touron et al, 2005).

\section{Denmark}

Official programmes for gifted education does not exist in Denmark (Baltzer et al, 2005). The term giftedness or gifted students is not mentioned in the school legislation. However, the recognition of individual differences is the fundamental guideline in the Danish school system. Identification of the individual needs of each student, choosing the appropriate teaching materials and methods should be ensured by teachers. Only few schools pay special attention to the gifted, there is a Royal Ballet School for talented dancers, music talents are educated at the Sct Anna Gymnasium and a lower secondary school in Odsherred offers special maths classes for gifted pupils. There are no identification processes for the gifted children in Denmark and there is no special training for teachers of gifted pupils. Only the two mentioned schools for ballet and music have special entrance exams for admission of gifted students. Some activities in the area of gifted education can be seen by private initiatives, such as the association Gifted Children Denmark, which groups gifted children, offers support and organises summer camps. Many teachers are still sensitive to

the topic of gifted education and there is a lack of political recognition and legislative considerations regarding gifted children. Silverman (2013) emphasises the need for gifted education in Denmark, as the gifted do not receive the needed attention and do not develop their potentials.

\section{Finland}

The school legislation in Finland does not mention gifted students explicitly or as a group of students with special educational needs. The education system is strongly decentralised and deregulated. At the national level only general guidelines are provided. The legislation acknowledges individual differences and allows schools to arrange teaching according to the age level and abilities of the students. Early entrance to primary schools, choosing subjects other than the ones in the national curriculum, skipping classes, sharing classes with higher grades, acceleration, workshops, extracurricular activities are possible in the Finish education system. Finland follows a strong direction toward individualisation. Schools have been encouraged to provide more individual curricula, which allow teaching to be more differentiated. The differentiation of education is a general policy and therefore the gifted pupils can benefit from this system. The un-grades system is very flexible and it allows pupils to accelerate depending on their abilities. The trend for parents is to choose a school which would suit the best their children's needs. Gifted students at the secondary school level 
join various competitions, or summer courses at universities. There are no official procedures or nominations for gifted children. One exception is the early entrance to school, where psychological and medical tests are required (Tirri, 2005). Even though, there is a lack of specific legislation concerning gifted education in Finland, the system appears to work very well (not only for the gifted children), as Finish students regularly finish at the top of international assessments, for example in PISA testing (OECD, 2014).

\section{Hungary}

Gifted education in Hungary has a long tradition. After the Second World War, nurturing the gifted has become a priority of Hungarian education. The Hungarian legislation recognises the gifted as pupils with special educational needs. Systematic development and innovation in the past decades have resulted in significant progress in the gifted education. Stockton (2009) reports, that Hungarian students have traditionally been very successful in international competitions and mathematics Olympiads. Hungarian system of specialised schools for mathematically gifted is believed to be original and this model was adopted by Russia and also the United States. Schools and teachers are responsible for identification and recognition of individual differences and talents of their pupils. The selection and identification process of the gifted children in Hungary is based on several criteria, such as the within school achievement, external achievement (competitions), teacher nomination, third party nomination and the psychologists' nomination based on psychological tests.

In Hungary, the enrichment is the preferred format for the gifted. Acceleration, grade skipping and sharing classes with higher grades is very uncommon. The gifted pupils can be offered a special curriculum, special classes, workshops and extra-curricular activities. There are special schools for the gifted in different areas of talents, from intellectual, music, arts to sports. The gifted education is successfully developed from the primary to the end of secondary education. There were 22 secondary schools in 2006 in Hungary, which followed a five year programme for the gifted. These courses were frequently evaluated to ensure an optimal development of the gifted students. There is a long tradition of organising regional or national competitions for students with many types of abilities (ibid.). Government regulations make it compulsory to include the education for the gifted in the fundamental teacher training. Every student has $20-30$ contact lessons during their training and the topics include identification, giftedness and age, giftedness and creativity, school programmes, cooperation of school and family, underachievement of the gifted, special role of the teachers in the gifted education, special fields of the gifted education, etc. Gifted education in Hungary has support and recognition from the state, schools and private initiatives on a very high level. More and more teachers take part in further training and the plan is to have one specialist in gifted education in every school, who would coordinate work with the gifted (Balogh et al, 2005; Gyarmathy, 2013).

\section{Czech Republic}


Gifted education does not have a long tradition in the Czech Republic. In the communist regime, any form of giftedness was considered as unsuitable elitism. Even though in the 1960s there were found special classes developing certain areas (languages, maths, sports), there was nothing special done in the gifted education. There were many requests from psychologists and educators for consideration of the gifted children in educational process. One of the first documents mentioning the gifted education was the National Programme for the Development of Education "White book" in 2000 and it contains a passage emphasising the importance of education for the gifted children in the areas of intellect, art, sports, etc. (Simonik, 2010). Education Programme Framework for Elementary education from 2004 specified the role of schools in education of the gifted children and the School Act 561 officially recognised the gifted education.

Today, gifted education is by legislation defined as education of pupils with special educational needs. The national curriculum sets it as a priority to identify and nourish the needs of gifted individuals, who would be able to achieve recognition in the competition with other countries. Children have to be identified as gifted by pegagogical-psychological advisory services. There are three possibilities of gifted education: integration, special classes and special schools for gifted children. According to Stava (2010) integration is the preferred model with the use of special methods, approaches, forms and materials, which would guarantee the development of gifted children. Individual learning programme, acceleration, enrichment, early enrolment to primary school, grade skipping are possible forms of gifted education.

In 2008, the Czech School Inspection published a report showing insufficiencies in educating the gifted children. According to research done by Simonik (2010), teachers were aware of the need to support education of gifted children, but they claimed that they received inadequate education on how to work with gifted pupils. Teachers also believed that there was a very little chance to work systematically with gifted children in the environment of a standard classroom. Simonik (ibid.) claimed that gifted education in the Czech Republic was on a very low level, where individual teachers or small groups of teachers were making effort to work with gifted children, often improvising. Teachers do not receive appropriate training and there are not available appropriate materials, methodologies and conditions for educating the gifted children. There is not a centralised care and information about support provided for gifted children in the Czech Republic. However, there are several institutions providing care and support via afternoon hobby classes, courses, weekend, virtual schools and summer camps and competitions (e.g. olympiads in maths, foreign languages, history, etc.) (Kovarova, Klugova, 2009). Mensa CR (2015) has established many clubs around the country for the support of gifted children. The aim is to identify highly gifted children at an early age and support their development. These clubs cooperate closely with local authorities, primary schools and parents. They provide supporting meetings 
at least once in two weeks, excursions, lectures and activities developing intellectual abilities of talented children.

\section{Slovakia}

History of gifted education in Slovakia goes back to the 1970s, when the Research Institute for Child Psychology and Patopsychology (VÚDPaP) started researching the issue of giftedness. They were trying to analyse specifics of mathematical, language, sport and artistic giftedness. Before the 1970s giftedness was considered as an elitist matter not acceptable in the communist regime. However, even at that time special schools developing talents existed, e.g. conservatoires, art schools, sport centres, etc. These schools and centres were developing only artistic or sport talents of children. In 1960s, as a reaction to the world trends to develop intellectually gifted children, special classes focusing on mathematics, language or sports began to be established. These classes offered more lessons of maths per week or early start of learning a foreign language. Different competitions and Olympiads from mathematics, physics, chemistry, geography, biology and foreign languages came to existence with the aim to stimulate talents of pupils (Laznibatova, 2008). In 1990s, after the end of the communist regime in 1990s, the real changes in gifted education started to happen.

In 1991, an Association for gifted children was founded. In 1993 Laznibatova started an experimental Project of alternative education for gifted children in segregated classed or schools at the primary school level. (Laznibatova, 1996, 2001, 2008; Dockal, 2005). After the Project of educating gifted children was approved by the Ministry of Education in May 1993 - the first experimental classroom for gifted children was opened in September 1993 in Bratislava. In 1998 the first school for gifted children was officially established in Bratislava, with Laznibatova as the director. In 1999 was also opened a 8-year-gymnasium as a part of the School for gifted children in Bratislava (SpMNDaG). In 2007 the experimental verification of the Project, which had been carried out between September 1993 and June 2007, was officially evaluated. The official evaluation took place at a conference with the presence of representatives of the three guarantors (National Institute for Education, Faculty of Education at the Comenius University, Research Institute for Child Psychology and Pathopsychology), representatives of the Ministry of Education, representatives of the Eurocommissary for education, and also many other specialists, school directors, teachers, psychologists and parents. Results of experimental verification were evaluated as highly effective and successful.

Based on these results, new alternative curricular documents were accredited in 2007 and modified in the process of curricular reform in 2009:

a) curriculum for primary education ISCED1 for pupils with general intellectual giftedness (accredited by the Ministry of Education CD-2008-18550/39582-1:914, valid from $26^{\text {th }}$ May 2009)

b) curriculum for lower secondary education ISCED2 for pupils with general intellectual giftedness (accredited by the Ministry of 
Education CD-2008-18550/39582-1:914, valid from $26^{\text {th }}$ May 2009)

c) curriculum for secondary education ISCED3 for pupils with general intellectual giftedness (accredited by the Ministry of Education CD-2008-18550/39582-1:914, valid from $26^{\text {th }}$ May 2009) (VÚDPaP, 2015).

In the process of curricular reform in Slovakia, the School act 245/2008 § 6 was passed, which introduced two levels of curriculum: the national curriculum and the school curriculum. The national curriculum serves as a base document for creating curricular documents for pupils with specific educational needs. A School act 245/2008 § 2 letter j) and q) specifies gifted children (pupils) as children with specific educational needs. Children with special educational needs have to be identified by centres of pedagogical-psychological advisory services. According to $\S 103$ (1), special schools offer education for children with:

a) intellectual giftedness (general and specific),

b) artistic giftedness

c) giftedness in sport (VUDPaP, 2015).

The national curriculum $\S 103$ (1) letter a) number 1 specifies the key stages, core subjects, expected standards of pupils' performance for pupils with general intellectual giftedness. The key competences, which pupils have to acquire, are the same as for the regular pupils. Accordingly, the principles and standards are the same in the national curriculum for both, the regular pupils and for pupils with general intellectual giftedness. The reason for the same standards is for compatibility of all schools, which is necessary in the case when pupils change schools (ibid.).

Another difference in the curricula for pupils with general intellectual giftedness is that the special educational needs of talented children have to be considered, and consequently, suitable approaches, methods, techniques and activities should be implemented. The personal, emotional and social peculiarities and differences in the level of development of gifted children needs to be recognized. Teachers should apply a highly individual approach to pupils and need to regard peculiarities of gifted children (sensitivity, communicativeness, individualism, anxiety, imagination, ambitions, perfectionism, hyperactivity, etc.) with the aim to develop their talents adequately (VUDPaP, 2015).

There are two ways of educating gifted children in Slovakia. One form of educating talented children is a model of segregated education. Another form of educating talented children is a model of integrated education (Dockal, 2005; Duchovicova, Babulicova, Gunisova, 2010; Koncepcia rozvoja nadanych deti a mladeze, 2007). The model of segregated education of gifted children has several principles. Apart from the minimum requirements set in the national curriculum, there are certain modifications: small number of pupils in classes (12), accelerated teaching with elements of extended and profound teaching, English language, Informatics and an "Enrichment subject" (special subject, in which pupils gain skills such as learning through discovery, creative problem solving, 
presentation of interesting topics, such as dinosaurs, the seas and oceans, traveling with Felix, Greek legends, etc.), elaborating projects (depending on the children's interests), elaborating annual projects (which are the main projects of the school year), new forms of evaluation and self evaluation, support and stimulation of children towards the higher forms of thinking and creativity, specific atmosphere at lessons, empathy and tolerance being the main features, pedagogical and psychological factors being present at equal level in the process of education (Juraskova, 2006).

Today, the Research Institute for Child Psychology and Pathopsychology (VUDPaP, 2015) is the only workplace in Slovakia that is focused on research of psychological aspects of child and youth development. The Institute also organizes educational courses for pedagogical staff who work with gifted children.

\section{Conclusion}

By researching gifted education systems in Europe, I came to conclusion that most gifted programmes are designed for the ambitious and high achieving individuals and the underachievers are left out. This view is also supported by Silverman (2013) who also adds that giftedness is largely invisible. The visibly gifted are high achievers, who represent the tip of the iceberg. The vast majority of the gifted are hidden from the view. Responsibility for identifying the gifted is put down to schools, teachers and parents. Teachers in general do not receive much education concerning the gifted children during their teacher training. Consequently they are not always able to recognize the giftedness in their pupils. Silverman (ibid.) believes that psychologists should be scouts seeking the gifted individuals in all groups. Professionals who specialise in the gifted can recognize the "gold beneath the surface" (ibid., p. 17). To conclude, I believe that gifted children need to be recognized. They need professionals who understand the issues of giftedness, their striving, their search for meaning, their desire for connection, and their complexity, sensitivity and intensity. Without deliberate search for the gifted and sensitive school programmes for all the gifted (including underachievers), there will not be successful and fair education for all gifted individuals.

\section{Bibliography}

BALOGH. L. et al. 2005. Country specific information - Hungary. Monks, F.J., Pfluger, R. (ed.) Gifted Education in 21 European Countries: Inventory and Perspective. Radboud University Nijmengen. Available online: https://www.bmbf.de/pub/gifted_education_21_eu_countries.pdf.

BALTZER, K. et al. 2005. Country specific information - Denmark. Monks, F.J., Pfluger, R. (ed.) Gifted Education in 21 European Countries: Inventory and Perspective. Radboud University Nijmengen. Available online www.bmbf.de/pub/gifted_education_21_eu_countries.pdf.

BIROVA, J. 2013. About Theoretical Definitions of Pluralistic and Pluricultural Approaches. XLinguae, Vol. 6. N. 2. ISSN 13378384.

BUNDESGESCHÄFTSSTELLE bochum. 2015. Hochbegabten-förderung e.V. Available online: www.hbf-ev.de/index.php?id=11. 
CASEY, R. - KOSHY, V. 2012. Gifted and Talented Education: The English Policy Highway at a Crossroads? Brunel University. Available online: http://bura.brunel.ac.uk/bitstream/2438/8266/2/Fulltext.pdf.

DEPARTMENT of education (DE). 2009. National Academy for Gifted and Talented Youth (NAGTY). Available online: https://www.gov.uk/government/publications/national-academy-for-giftedand-talented-youth-evaluation.

DEPARTMENT for children, school and families (DCSF). 2008. Identifying gifted and talented learners - getting started. Available online: http://webarchive.nationalarchives.gov.uk/20130401151715/http://www.ed ucation.gov.uk/publications/eOrderingDownload/Getting\%20StartedWR.pd f.

DGhK. 2015. Die Deutsche Gesellschaft für das hochbegabte Kind.

Available online:www.dghk.de/wir-ueber-uns.

DOCKAL, V. 2005. Zamereno na talenty, aneb, Nadani ma kazdy. Prague: Nakladatelstvi Lidove noviny, pp. 7-13, 23-26, 91-97, 132, 179-189. ISBN 8071068403.

DUCHOVICOVA, J. - BABULICOVA, Z. - GUNISOVA, D. 2010. Tvorivost, nadanie a ich neurodidakticky rozmer. Strategicky vyznam inovacii $\mathrm{v}$ edukacnej teorii a praxi. Nitra: UKF, 2010. ISBN 9788080947743, p. 7.

EYRE, D. 2004. Gifted Education: The English Model. Available online: www.potentialplusuk.org/file_upload/GT\%20English\%20Model-deboraheyre\%20\%282\%29.pdf.

EYRE, D. 2009. The English Model of Gifted Education. Shavinina, L. International Handbook on Giftedness. Springer. ISBN: 9781402061615.

FISHER, C. et al. 2005. Country specific information - Germany. Monks, F.J., Pfluger, R. (ed.) Gifted Education in 21 European Countries: Inventory and Perspective. Radboud University Nijmengen. Available online: https://www.bmbf.de/pub/gifted_education_21_eu_countries.pdf.

GROSSENBACHER, S. 2005. Country specific information - Switzerland. In: Monks, F.J., Pfluger, R. (ed.) Gifted Education in 21 European Countries: Inventory and Perspective. Radboud University Nijmengen. Available online: www.bmbf.de/pub/gifted_education_21_eu_ countries.pdf.

GYARMATHY, E. 2013. The Gifted and Gifted Education in Hungary. Journal for the Education of the Gifted. Vol. 36. No. 1, pp. 19-43. ISSN 01623532.

HENRY, J. 2010. Ministers pull the plug on gifted and talented academy. The Telegraph.. Available online: www.telegraph.co.uk/ed ucation/educationnews/7062061/Ministers-pull-the-plug-on-gifted-andtalented-academy.html.

HERRMANN, A. - NEVO, B. 2011. Gifted Education in German Speaking Countries. Gifted and Talented International. Vol. 26, No 1, 2, p. 47-63. ISSN: 15332276.

JURASKOVA, J. 2003. Zaklady pedagogiky nadanych. Pezinok: Format. ISBN: 808900511. 
JURASKOVA, J. 2006. Nadanie.sk O intelektovom nadani pre kazdeho. Available online: www.nadanie.sk/index.php?ID=12.

KONCEPCIA rozvoja nadanych deti a mladeze v SR. 2007. Available online: www.minedu.sk/data/USERDATA/RegionalneSkolstvo/SpVaV/ Materialy/Koncepcia_rozvoja_nadanych_deti.pdf .

KOVAROVA, R. - KLUGOVA, I. 2009. Edukace nadanych deti a zaku. Synergie projekt c. CZ.1.07./2.2.00/07.0355. Available online: http://projekty.osu.cz/synergie/dok/opory/kovarova-edukace-nadanychdeti-a-zaku.pdf.

LAZNIBATOVA, J. et al. 2008. 10 rokov zalozenia skoly pre mimoriadne nadane deti a Gymnazium, 1.1. 1998 - 1.1.2008. Bratislava. 2008.

LAZNIBATOVA, J. 2001. Nadane dieta: jeho vyvin, vzdelavanie a podporovanie. 1. vyd. Bratislava: Iris, ISBN 8088778328.

LAZNIBATOVA, J. (ed.) 2008. Od rozvijania nadania k rozvijaniu osobitosti nadanych. Zbornik prac z 5. Medzinarodnej konferencie. Bratislava: Iris.

LAZNIBATOVA, J. 1996. Problemy vychovy a vzdelavania nadanych deti. (Projekt starostlivosti o nadane deti $\mathrm{v}$ podmienkach zakladnych skol). Pedagogicka revue. Vol. 1, No. 1-2, pp. 79-84.

LALINSKA, M. 2012. Posudenie cudzojazycnej kompetencie ziakov na vystupe z 1. stupna ZS v SR. XLinguae Journal. Vol. 5. No. 4, ISSN 13378384.

MENSA CR. 2015. Mensa CR: Pro nadane deti. Available online: http://deti.mensa.cz/.

MÖNKS, F.J. - PFLUGER, R. 2005. Gifted Education in 21 European Countries: Inventory and Perspective. Radboud University Nijmengen. Available online: www.bmbf.de/pub/gifted_education_21_eu_ countries.pdf.

MURAY, J. 2010. Farewell to the gifted and talented scheme. The Guardian. Available online: http://www.theguardian.com/education/2010/ feb/02/gifted-talented-scrapped-funds-redirected.

OECD. 2014. PISA 2012 Results. Available online: http://www.oecd.org/pisa/keyfindings/pisa-2012-results.htm.

OSWALD, F. at al. 2005. Country specific information - Austria. Monks, F.J., Pfluger, R. (ed.) Gifted Education in 21 European Countries: Inventory and Perspective. Radboud University Nijmengen. Available online: www.bmbf.de/pub/gifted_education_21_eu_countries.pdf.

PERSSON, R.S. - JOSWIG, H. - BALOGH, L. 2000. Gifted Education in Europe: Programs, Practices and Current Research. Heller, K.A. et al.: International Handbook of Giftedness and Talent. Oxford: Elsevier. ISBN 0080437966.

POTENTIALPLUSUK. 2014. Available online: www.potentialplusuk.org/ general.php?webid=457\#.U9YxOUAtIdU.

SILVERMAN, L. 2013. Why Does Denmark Need Gifted Education? Gifted Children's Symposioum. Danish Associatin for Gifted Children. Soro, Denmark. Available online: www.giftedchildren.dk/content.php?735Linda-Silverman-Why-Does-Denmark-Need-Gifted-Education. 
STOCKTON, J. C. 2009. Hungary and the United States: A Comparison of Gifted Education. Mathematics Faculty Publications. Paper 8. Available online: http://digitalcommons.sacredheart.edu/cgi/viewcontent.cgi?article $=1007 \&$ context $=$ math_fac.

SIMONIK, O. (ed.) 2010. School and talented pupil. Vyzkumny zamer MSM0021622443. Brno: MU. ISBN 9788021053502.

STAVA, J. 2010. Pristupy k nadanym zakum v soucasne skole; legislativa moznych pristupu skol a ucitelu k nadanym zakum. Simonik, O. (ed.) Vzdelavani nadanych zaku. Brno: Masarykova Univerzita. ISBN: 978-80210-5349-6.

TIRRI, K. 2005. Country specific information - Finland. Monks, F.J., Pfluger, R. (ed.) Gifted Education in 21 European Countries: Inventory and Perspective. Radboud University Nijmengen.

TOURON, J. et al. 2005. Country specific information - Spain. Monks, F.J., Pfluger, R. (ed.) Gifted Education in 21 European Countries: Inventory and Perspective. Radboud University Nijmengen. Available online: https://www.bmbf.de/pub/gifted_education_21_eu_countries.pdf.

VAN TASSEL-BASKA, J. 2013. The World of Cross-Cultural Research: Insight for Gifted Education. In: Journal for the Education of the Gifted. Vol. 36. No. 1. pp. 6-18. ISSN 0162-3532.

VUDPaP. 2015. Vyskumny ustav detskej psychologie a patopsychologie. Vzdelavacie programy pre ziakov so vseobecnym intelektovym nadanim. Available online: www.vudpap.sk/informacie-pre-pedagogov/.

WEILGUNY, M. W. - RESCH, C. - SAMHABER, E. - HARTEL, B. 2013. White Paper promoting talent and excellence. Available online: www.oezbf.at/cms/tl_files/Publikationen/Veroeffentlichungen/weissbuch_ E_fertig_interaktiv.pdf.

ZIEGLER, A. - STOEGER, H. - HARDER, B. - BALESTRINI, D.P. 2013. Gifted Education in German-Speaking Europe. Journal for the Education of the Gifted. Vol. 36. No. 3, pp. 384. ISSN 01623532.

Mgr. Eva Reid, PhD.

Constantine the Philosopher University in Nitra

Faculty of Education

Department of Language Pedagogy and Intercultural Studies

Drážovská cesta 4, 94974 Nitra

ereid@ukf.sk

prof. Heiner Boettger, $\mathrm{PhD}$.

Catholic University of Eichstaett-Ingolstadt

Department of Linguistics and Literature

Universitätsallee 1, 85072 Eichstätt

heiner.boettger@ku.de 